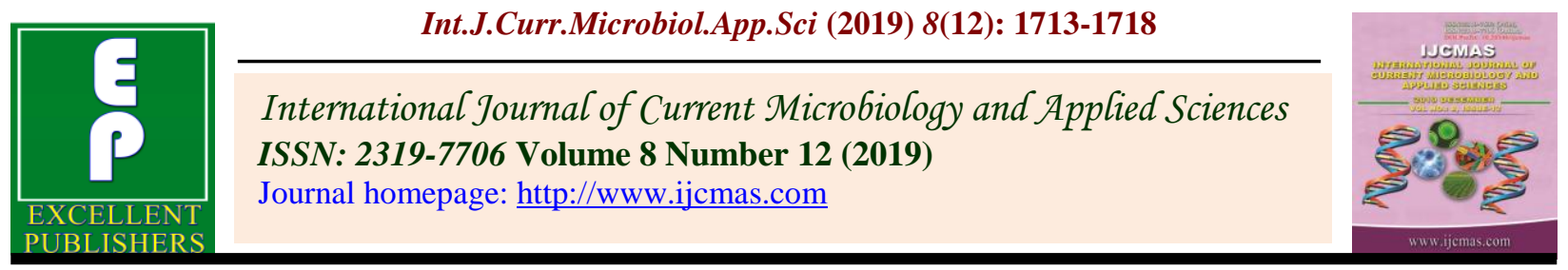

Original Research Article

https://doi.org/10.20546/ijcmas.2019.812.206

\title{
Studies on Physico-Chemical Changes during Storage of Different Varieties of Kiwifruit or Chinese Gooseberry (Actinidia deliciosa) under Ambient Conditions
}

\author{
Aascharya Pandey*, V. M. Prasad, Sudhir Kumar Mishra and Deepak Lall
}

Department of Horticulture, Sam Higginbottom University of Agriculture, Technology and Sciences, Allahabad-211007, India

*Corresponding author

\section{A B S T R A C T}

\begin{tabular}{|l|}
\hline Ke y w o r d s \\
Kiwi fruit \\
(Actinidia \\
deliciosa), LDPE \\
and BROWN \\
PAPER bagging \\
with silica gel \\
crystal \\
\hline Article Info \\
\hline $\begin{array}{l}\text { Accepted: } \\
15 \text { November } 2019 \\
\text { Available Online: } \\
\text { 10 December } 2019\end{array}$ \\
\hline
\end{tabular}

\section{Introduction}

Kiwifruit (Actinidia deliciosa) is well known as a nutritious fruit due to its high contents of ascorbic acid (vitamin $\mathrm{C}$ ), potassium, folic acid and antioxidants (e.g. polyphenols, carotenoids). Kiwifruit is perhaps the best known nutritious fruit amongst the other soft fruits. As its name indicates, the plant is of Chinese origin where the vigorous woody vine is present. The kiwifruit is rusty brown with hairy surface, oblong in shape, look like a sapota fruit. The brown hairs disappear by rubbing in muslin cloth/gunny bag after harvesting. A ripe fruit is refreshing, delicate flavour with pleasing aroma and high nutritive 
value. The nutritive value and flavour are retained when the fruit is processed to jam, jelly or preserves. Early varieties were described in a 1904 nursery catalogue as having edible fruits with the size of walnuts, and the flavour of ripe gooseberries", leading to the name Chinese gooseberry.

\section{Materials and Methods}

An experiment entitled "Studies on Physicochemical changes during storage of different varieties of kiwifruit under ambient condition" was conducted in the Post Harvest Laboratory, Department of Horticulture, Nani Agricultural Institute, Sam Higginbottom University of Agriculture, Technology and Sciences, Prayagraj during the year 2018 - 2019. Kiwi were purchased from NBPGH (ICAR) Regional station Bhowali, Uttrakhand on $04^{\text {th }}$ November, 2018. On $6^{\text {th }}$ November, 2018 bagging of kiwi fruit was started with LDEP, Brown paper bags along with silica gel crystal as compared to Control (without bagging). Observations recorded were physical, chemical properties and self life of Kiwi fruits. The estimation of fruits quality and shelf life of different five varieties viz. $\mathrm{V}_{1}-$ Allison, $\mathrm{V}_{2^{-}}$ Bruno, $\mathrm{V}_{3}$-Monty, $\mathrm{V}_{4}$-Hayward and $\mathrm{V}_{5^{-}}$ Abbott of Kiwi fruits undergone with 15 treatments where each will be replicated thrice and stored for about 21 days under ambient temperature. The Experiment is laid out under Complete Randomized Block Design (CRD) (Table 1).

\section{Results and Discussion}

Effect of different wrapping material with silica gel crystal on physical properties of kiwi fruit (Actinidia deliciosa)

The data on mean fruit weight $(\mathrm{g})$, fruit length $(\mathrm{cm})$, fruit width $(\mathrm{cm})$ and physiological loss weight ( $\mathrm{g}$ ) after wrapping as influenced by LDPE Bags and Brown paper Bags in different treatment combinations was recorded and are presented in table 2. Critical analysis of data displayed in table clearly marked out the obvious difference among the treatments with respect to mean fruit weight $(\mathrm{g})$, fruit length $(\mathrm{cm})$, fruit width $(\mathrm{cm})$ and physiological loss weight (g).

Based on the data it is found that the treatment $\mathrm{T}_{4}$ (Wrapped in LDPE bags with silica gel crystal) found maximum $(83.15 \mathrm{~g})$ mean fruit weight after 21 days of Wrapping followed by $\mathrm{T}_{2}$ (Wrapped in LDPE bags with silica gel crystal) (78.79g) after 21days of wrapping, where as minimum fruit weight $(58.50 \mathrm{~g})$ was recorded with $\mathrm{T}_{8}$ (Wrapped in Brown Paper bags with silica gel crystal). Similar findings were also reported by Tefera et al., (2007) and Tripathi and Thakur (2002).

Based on the data it is found that the treatment $\mathrm{T}_{4}$ (Wrapped in LDPE bags with silica gel crystal) found maximum $(4.54 \mathrm{~cm})$ fruit length after 21 days of Wrapping followed by $\mathrm{T}_{13}$ (Control) after 21days of rapping, where as minimum Mean fruit length $(2.53 \mathrm{~cm})$. Similar findings were also reported by Kumar (2006) and Tripathi and Thakur (2002).

Based on the data it is found that the treatment $\mathrm{T}_{4}$ (Wrapped in LDPE bags with silica gel crystal) found maximum $(3.58 \mathrm{~cm})$ mean fruit width after 21 days of Wrapping followed by $\mathrm{T}_{11}$ (Control) after 21days of Wrapping, where as minimum Mean fruit width $(1.49 \mathrm{~cm})$. Similar findings were also reported by Patil and Hulamani (1998).

Based on the data it is found that the treatment $\mathrm{T}_{15}$ (Control) found maximum (4.80g) Physiological loss weight (g) after 21 days of Wrapping followed by $\mathrm{T}_{4}$ (Wrapped in LDPE Bags with Silica Gel Crystals) after 21days of Wrapping, where as minimum Physiological loss weight (g) (2.33g). Similar findings were also reported by Tripathi and Thakur (2002) and Rangavalli et al., (1993). 
Effect of different wrapping material with silica gel crystal on chemical properties of kiwi fruit (Actinidia deliciosa)

The data on TSS ${ }^{\circ}$ Brix, Vitamin $\mathrm{C}$ (mg), Acidity (\%), Reducing sugar, Non-reducing sugar, Total sugar and Spoilage (\%) after wrapping as influenced by LDPE Bags and Brown paper Bags in different treatment combinations was recorded and are presented in table 3. Critical analysis of data displayed in table clearly marked out the obvious difference among the treatments with respect on TSS ${ }^{\mathrm{O}}$ Brix, Vitamin C (mg), Acidity (\%), Reducing sugar, Non-reducing sugar, Total sugar and Spoilage (\%).

Based on the data it is found that the treatment $\mathrm{T}_{7}$ (Wrapped in Brown paper bags with silica gel crystal) found maximum $\left(19.92^{\circ}\right.$ Brix $)$ Total Soluble Solid ${ }^{0}$ Brix after 21 days of Wrapping followed by $\mathrm{T}_{4}$ (Wrapped in LDPE with silica gel crystal) after 21days of wrapping, where as minimum Total Soluble Solid ${ }^{0}$ Brix $\left(13.83^{0}\right.$ Brix $)$. Similar findings were also reported by Tripathi and Thakur (2002).

Based on the data it is found that the treatment $\mathrm{T}_{4}$ (Wrapped in LDPE bags with silica gel crystal) found maximum (135.46) Vitamin C $(\mathrm{mg} / 100 \mathrm{~g}) .21$ days of Wrapping followed by $\mathrm{T}_{7}$ (Wrapped in Brown bags with silica gel crystal) after 21days of wrapping, where as minimum Vitamin C (mg/100 g). (30.75). Similar findings were also reported by Tefera et al., (2007) and Tripathi and Thakur (2002). Based on the data it is found that the treatment $\mathrm{T}_{2}$ (Wrapped in LDPE bags with silica gel crystal) found maximum (1.49) Acidity (\%) 21 days of Wrapping followed by $\mathrm{T}_{4}$ (Wrapped in LDPE Bags with Silica Gel Crystals) after 21days of wrapping, where as minimum Acidity (\%) (0.75). Similar findings were also reported by Kumar (2006) and Tripathi and Thakur (2002).

Table.1 Treatment details

\begin{tabular}{|c|c|c|}
\hline $\begin{array}{c}\text { Treatments } \\
\text { Symbol }\end{array}$ & $\begin{array}{c}\text { Treatment (Based on } \\
\text { Kiwi fruit varieties) }\end{array}$ & Wrapping Material Used \\
\hline $\mathbf{T}_{\mathbf{1}}$ & $\mathrm{V}_{1}$-ALLISON & Wrapped in LDPE Bags with Silica Gel Crystals \\
\hline $\mathbf{T}_{\mathbf{2}}$ & $\mathrm{V}_{2}$-BRUNO & Wrapped in LDPE Bags with Silica Gel Crystals \\
\hline $\mathbf{T}_{\mathbf{3}}$ & $\mathrm{V}_{3}$-MONTY & Wrapped in LDPE Bags with Silica Gel Crystals \\
\hline $\mathbf{T}_{\mathbf{4}}$ & $\mathrm{V}_{4}$-HAYWARD & Wrapped in LDPE Bags with Silica Gel Crystals \\
\hline $\mathbf{T}_{\mathbf{5}}$ & $\mathrm{V}_{5}-$ ABBOTT & Wrapped in LDPE Bags with Silica Gel Crystals \\
\hline $\mathbf{T}_{\mathbf{6}}$ & $\mathrm{V}_{1}$-ALLISON & Wrapped in Brown Paper Bags with Silica Gel Crystals \\
\hline $\mathbf{T}_{\mathbf{7}}$ & $\mathrm{V}_{2}$-BRUNO & Wrapped in Brown Paper Bags with Silica Gel Crystals \\
\hline $\mathbf{T}_{\mathbf{8}}$ & $\mathrm{V}_{3}$-MONTY & Wrapped in Brown Paper Bags with Silica Gel Crystals \\
\hline $\mathbf{T}_{\mathbf{9}}$ & $\mathrm{V}_{4}$-HAYWARD & Wrapped in Brown Paper Bags with Silica Gel Crystals \\
\hline $\mathbf{T}_{\mathbf{1 0}}$ & $\mathrm{V}_{5}-$ ABBOTT & Wrapped in Brown Paper Bags with Silica Gel Crystals \\
\hline $\mathbf{T}_{\mathbf{1 1}}$ & $\mathrm{V}_{1}$-ALLISON & CONTROL \\
\hline $\mathbf{T}_{\mathbf{1 2}}$ & $\mathrm{V}_{2}$ BRUNO & CONTROL \\
\hline $\mathbf{T}_{\mathbf{1 3}}$ & $\mathrm{V}_{3}$ MONTY & CONTROL \\
\hline $\mathbf{T}_{\mathbf{1 4}}$ & $\mathrm{V}_{4}$-HAYWARD & CONTROL \\
\hline $\mathbf{T}_{\mathbf{1 5}}$ & $\mathrm{V}_{5}$-ABBOTT & CONTROL \\
\hline
\end{tabular}


Table.2 Effect of different wrapping material with silica gel crystal on physical properties of kiwi fruit (Actinidia deliciosa)

\begin{tabular}{|c|c|c|c|c|c|}
\hline \multirow{2}{*}{$\begin{array}{c}\text { Treatment } \\
\text { No. }\end{array}$} & \multirow[t]{2}{*}{ Treatment combination } & \multicolumn{4}{|c|}{ Physical properties } \\
\hline & & $\begin{array}{c}\text { Mean } \\
\text { fruit } \\
\text { weight } \\
\text { (g) }\end{array}$ & $\begin{array}{l}\text { Fruit } \\
\text { length } \\
\text { (cm) }\end{array}$ & $\begin{array}{l}\text { Fruit } \\
\text { width } \\
\text { (cm) }\end{array}$ & $\begin{array}{l}\text { Physiological } \\
\text { loss weight } \\
\text { (g) }\end{array}$ \\
\hline $\mathbf{T}_{1}$ & $\begin{array}{l}\text { Wrapped in LDPE Bags with } \\
\text { Silica Gel Crystals }\end{array}$ & 69.25 & 3.78 & 2.42 & 2.38 \\
\hline $\mathbf{T}_{2}$ & $\begin{array}{l}\text { Wrapped in LDPE Bags with } \\
\text { Silica Gel Crystals }\end{array}$ & 78.79 & 4.06 & 2.98 & 2.49 \\
\hline $\mathbf{T}_{\mathbf{3}}$ & $\begin{array}{l}\text { Wrapped in LDPE Bags with } \\
\text { Silica Gel Crystals }\end{array}$ & 65.66 & 3.81 & 2.74 & 2.45 \\
\hline $\mathbf{T}_{4}$ & $\begin{array}{l}\text { Wrapped in LDPE Bags with } \\
\text { Silica Gel Crystals }\end{array}$ & 83.15 & 4.54 & 3.58 & 2.33 \\
\hline $\mathbf{T}_{5}$ & $\begin{array}{l}\text { Wrapped in LDPE Bags with } \\
\text { Silica Gel Crystals }\end{array}$ & 69.13 & 4.01 & 2.95 & 2.47 \\
\hline $\mathbf{T}_{6}$ & $\begin{array}{l}\text { Wrapped in Brown Paper Bags } \\
\text { with Silica Gel Crystals }\end{array}$ & 63.70 & 3.13 & 1.89 & 2.90 \\
\hline $\mathbf{T}_{7}$ & $\begin{array}{l}\text { Wrapped in Brown Paper Bags } \\
\text { with Silica Gel Crystals }\end{array}$ & 64.24 & 3.43 & 2.36 & 3.00 \\
\hline $\mathbf{T}_{8}$ & $\begin{array}{l}\text { Wrapped in Brown Paper Bags } \\
\text { with Silica Gel Crystals }\end{array}$ & 58.50 & 2.79 & 2.28 & 3.13 \\
\hline $\mathbf{T}_{9}$ & $\begin{array}{l}\text { Wrapped in Brown Paper Bags } \\
\text { with Silica Gel Crystals }\end{array}$ & 72.16 & 3.37 & 3.08 & 3.17 \\
\hline $\mathbf{T}_{10}$ & $\begin{array}{l}\text { Wrapped in Brown Paper Bags } \\
\text { with Silica Gel Crystals }\end{array}$ & 63.52 & 3.15 & 2.42 & 3.18 \\
\hline $\mathbf{T}_{11}$ & CONTROL & 59.15 & 2.77 & 1.49 & 4.35 \\
\hline $\mathbf{T}_{12}$ & CONTROL & 61.84 & 3.00 & 1.92 & 4.60 \\
\hline $\mathbf{T}_{13}$ & CONTROL & 59.81 & 2.53 & 1.77 & 4.47 \\
\hline $\mathbf{T}_{14}$ & CONTROL & 75.13 & 3.39 & 2.49 & 4.68 \\
\hline $\mathbf{T}_{15}$ & CONTROL & 59.81 & 2.72 & 1.86 & 4.80 \\
\hline F-test & & $\mathbf{S}$ & $\mathbf{S}$ & $\mathbf{S}$ & S \\
\hline $\begin{array}{l}\text { C.D. at } \\
5 \%\end{array}$ & & 0.211 & 0.259 & 0.087 & 0.012 \\
\hline S.Ed. ( \pm$)$ & & 0.103 & 0.127 & 0.042 & 0.006 \\
\hline
\end{tabular}


Table.3 Effect of different wrapping material with silica gel crystal on chemical properties of kiwi fruit (Actinidia deliciosa)

\begin{tabular}{|c|c|c|c|c|c|c|c|}
\hline \multirow[t]{2}{*}{ Treatment No. } & \multicolumn{7}{|c|}{ Chemical properties } \\
\hline & $\begin{array}{c}\text { TSS } \\
{ }^{0} \text { Brix }\end{array}$ & $\begin{array}{l}\text { Vitamin } \\
\mathrm{C}(\mathrm{mg})\end{array}$ & $\begin{array}{c}\text { Acidity } \\
(\%)\end{array}$ & $\begin{array}{l}\text { Reducing } \\
\text { sugar }\end{array}$ & $\begin{array}{l}\text { Non- } \\
\text { reducing } \\
\text { sugar }\end{array}$ & $\begin{array}{l}\text { Total } \\
\text { sugar }\end{array}$ & $\begin{array}{c}\text { Spoilage } \\
(\%)\end{array}$ \\
\hline $\mathbf{T}_{1}$ & 16.42 & 103.86 & 0.94 & 7.89 & 2.30 & 10.19 & 2.41 \\
\hline $\mathbf{T}_{2}$ & 17.16 & 35.22 & 1.49 & 7.89 & 1.75 & 9.64 & 3.15 \\
\hline $\mathbf{T}_{3}$ & 18.20 & 65.85 & 1.24 & 8.09 & 2.06 & 10.16 & 3.77 \\
\hline $\mathbf{T}_{4}$ & 13.83 & 135.46 & 0.72 & 9.22 & 1.79 & 11.01 & 2.15 \\
\hline $\mathbf{T}_{5}$ & 17.26 & 70.07 & 1.44 & 7.85 & 1.87 & 9.71 & 5.52 \\
\hline $\mathbf{T}_{6}$ & 16.74 & 88.90 & 1.73 & 8.05 & 2.19 & 10.24 & 4.45 \\
\hline $\mathbf{T}_{7}$ & 19.92 & 30.75 & 1.22 & 7.59 & 1.66 & 9.25 & 2.88 \\
\hline $\mathbf{T}_{8}$ & 14.77 & 59.38 & 1.08 & 8.91 & 1.83 & 10.74 & 3.15 \\
\hline $\mathbf{T}_{9}$ & 16.61 & 116.82 & 0.85 & 9.05 & 1.90 & 10.96 & 3.69 \\
\hline $\mathbf{T}_{10}$ & 16.86 & 76.55 & 1.36 & 8.26 & 1.68 & 9.93 & 3.41 \\
\hline $\mathbf{T}_{11}$ & 17.00 & 79.49 & 1.05 & 7.63 & 2.11 & 9.74 & 15.7 \\
\hline $\mathbf{T}_{12}$ & 16.22 & 37.38 & 1.38 & 7.75 & 1.87 & 9.62 & 18.27 \\
\hline $\mathbf{T}_{13}$ & 13.91 & 59.72 & 0.75 & 8.31 & 2.22 & 10.53 & 16.47 \\
\hline $\mathbf{T}_{14}$ & 15.44 & 109.48 & 0.75 & 9.25 & 1.92 & 11.17 & 16.55 \\
\hline $\mathbf{T}_{15}$ & 15.73 & 77.23 & 1.20 & 7.70 & 2.05 & 10.19 & 18.37 \\
\hline F-test & $\mathbf{S}$ & $\mathbf{S}$ & $\mathbf{S}$ & $\mathbf{S}$ & $\mathbf{S}$ & $\mathbf{S}$ & $\mathbf{S}$ \\
\hline C.D. at $5 \%$ & 0.581 & 0.928 & 0.080 & 0.280 & 0.069 & 0.283 & 0.844 \\
\hline S.Ed. (+) & 0.284 & 0.453 & 0.039 & 0.137 & 0.034 & 0.138 & 0.412 \\
\hline
\end{tabular}

Based on the data it is found that the treatment $\mathrm{T}_{4}$ (Wrapped in LDPE bags with silica gel crystal) found maximum (9.22) reducing sugar 21 days of Wrapping followed by $\mathrm{T}_{7}$ (Wrapped in Brown bags with silica gel crystal) after 21days of wrapping, where as minimum Reducing sugar (7.59). Similar findings were also reported by Tefera et al., (2007).

Based on the data it is found that the treatment $\mathrm{T}_{1}$ (Wrapped in LDPE bags with silica gel crystal) found maximum (2.30) non-reducing sugar 21 days of Wrapping followed by $\mathrm{T}_{4}$ (Wrapped in LDPE bags with silica gel crystal) after 21days of wrapping, whereas minimum non-reducing sugar (1.79). Similar findings were also reported by Kumar (2006).
Based on the data it is found that the treatment $\mathrm{T}_{4}$ (Wrapped in LDPE bags with silica gel crystal) found maximum (11.01) total sugar 21 days of Wrapping followed by $\mathrm{T}_{7}$ (Wrapped in LDPE bags with silica gel crystal) after 21days of wrapping, whereas minimum total sugar (9.25). Similar findings were also reported by Xu et al., (2001).

Based on the data it is found that the treatment $\mathrm{T}_{15}$ (Control) found maximum (18.37\%) spoilage (\%) 21 days of Wrapping followed by $\mathrm{T}_{4}$ (Wrapped in LDPE bags with silica gel crystal) after 21days of wrapping, whereas minimum spoilage @ $(2.15 \%)$. Similar findings were also reported by Tripathi and Thakur (2002). 
Based on above the finding of the present experiment it is concluded that treatment $\mathrm{T}_{4}$ that is (Hayward) variety Wrapped in LDPE Bags with Silica Gel Crystals was found most superior in respect of Physico-chemical changes, Organoleptic test and Overall Acceptability under ambient temperature. In terms of cost benefit ratio the highest net return, cost benefit ratio was also found associated with $\mathrm{T}_{4}$ LDPE bags with silica gel crystal $10 \mathrm{~g}$ (Hayward) variety respectively.

\section{References}

Amiruzzaman M. (1990). Postharvest handling and processing of fruits and vegetables. In: Kitchen Gardening and Homestead Production Activities. CIRDAP Action Res. Series No. 11: 22.

Kumar P (2006). Effect of packaging methods, temperature and ethylene on shelf life and quality of banana. Msc Thesis, Department of Horticulture and Postharvest Technology Sher - E Bangla Agricultural University Dhaka:
60.

Kumar, P. and Singh, S. (1993). Effect of GA3 and ethrel on ripening and quality of mango cv. Amrapali. Journal of Horticulture, 6(1): 19-23.

Patil, S. N. and Hulamani, N. C. (1998). Effect of post harvest treatments on physical characters and shelf life of banana fruits. Karnataka Journal of Agricultural Sciences, 11(2): 535-537.

Rangavalli, K., Ravisankar, C. and Prasad, P. H. (1993). Post harvest changes in mango (Mangifera indica L.) var. Banesham. South Indian Horticulture, 41(3): 169-70.

Tefera A, Seyoum T, Woldetsadik K. (2007). Effect of disinfection, packaging and storage environment on the shelf life of mango. Biosystematics Engineering, 97, 201-212.

$\mathrm{Xu}$, S., Chen, X. and Sun, D. (2001) Preservation of Kiwifruit Coated with an Edible Film at Ambient Temperature. Journal of Food Engineering, 50, 211-216.

\section{How to cite this article:}

Aascharya Pandey, V. M. Prasad, Sudhir Kumar Mishra and Deepak Lall. 2019. Studies on Physico-Chemical Changes during Storage of Different Varieties of Kiwifruit or Chinese Gooseberry (Actinidia deliciosa) under Ambient Conditions. Int.J.Curr.Microbiol.App.Sci. 8(12): 1713-1718. doi: https://doi.org/10.20546/ijcmas.2019.812.206 